Vol. XIV, No. 2

\title{
Museum Tours
}

Two letters from students who came from Birch Creek School, Bankend, to visit the Museum have been passed on to the Editor of the Blue Jay. Both Irene Borowski and Dianne Stefansson of the Grade VIII class describe enthusiastically their tour of the Museum. For the first time they saw the impressive display cases in the new Museum building and learned about the exhibits from Dr. Nero of the Museum staff. One of the display cases that Irene describes is the one showing the fur traders and Indians which is pictured in the Museum section on page 44 .

Irene tells of another display by which the school group was especially awed. Dr. Nero said to us, "I have a surprise for you, and I think it will be more impressive is you close your eyes until we've rounded the corner and I tell you to open them." Then, by following Dr. Nero's voice, we were able to round the corner without anything except a few bumps on the head for one boy who ran into the wall! But when we opened our eyes! Oh,. what a sight! "It's enough to make your blood run cold," I whispered to my friend, for there stood the "Monarchs of the Prairies," the buffalo, and very imposing and majestic animals they were!"

In the cpinion of Dianne Stefansson "the most remarkable exhibit was that of two wolves hunting under realistic, glorious moonlight, which seemed bluish and dazzling on a blanket of artificial, but seemingly real, snow." The enthusiasm of these two girls shows how much the Museum can do for the students in Saskatchewan schools, and we hope that these same students will get to know even more about the Museum section in the Blue Jay.

\section{News from the Prince Albert Natural History Society}

The Annual Meeting of the Prince Albert Natural History Society was held February 1, 1956, with the following officers elected: President Ross Homer; Past-President - E. W. Brooman; Secretary - Grace Crooks; Treasurer - T. Capusten; Directors D. Grieef, I. Collins, M. Welsh, Jean McKenzie, R. Mayson, H. Towell, Winifred Woods, E. G. Evasiuk, F. A. Trent, J. Johnson, $H$. Tomlinson. Annual fees were set at $\$ 1.00$ for adults and $50 \mathrm{c}$ for children.

This season the P.A. Society has completed a series of five lectures on botany dealing with collecting, classifying, and mounting; and a series of two lectures on ornithology, in preparation for field trips. The lectures on birds included points of recognition and habitat, skinning and taxidermy, North American bird calls and a film strip of 32 common birds.

The P.A. Society is to be congratulated for the stand it took recently on the trapping of beaver on the Little Red River. City Council rescinded a resolution permitting beaver trapping at the Little Red and North Sask. Rivers within city limits because of letters of protest received from the Natural History Society and the Fish and Game League.

\section{FLICKER PHOTO}

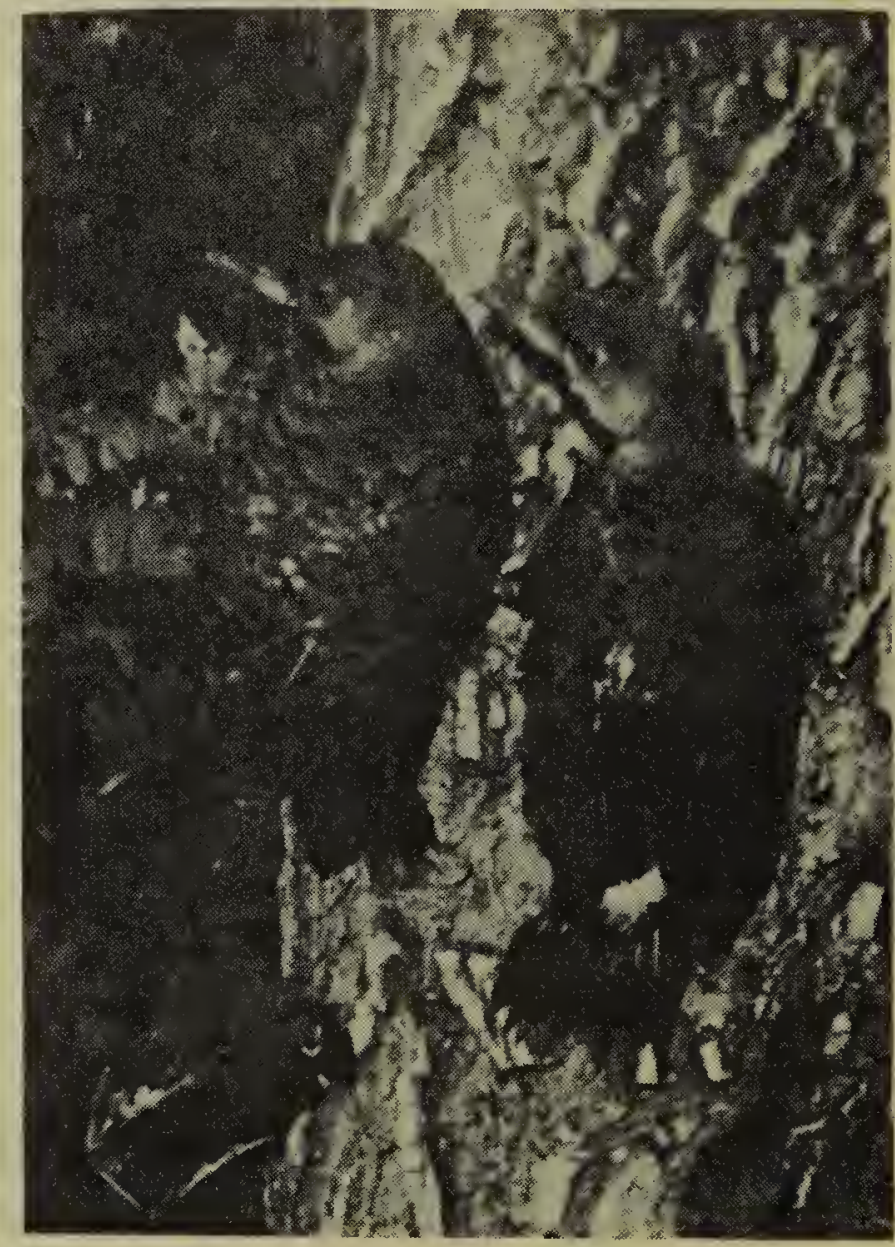

- Photo by A. Capusten

Two young Yellow-shafted Flickers photographed by Tony Capusten, Prince Albert. These two Flickers from a nest in a dying poplar, were found in a weakened condition and fed buttered toast, raw wet oatmeal, hamburger, and earthworms. In a few days they were again quite active, thanks to $\mathrm{Mr}$. Capusten's care. 